Received: 12 November 2018 Accepted: 23 May 2019 Published online: 05 June 2019
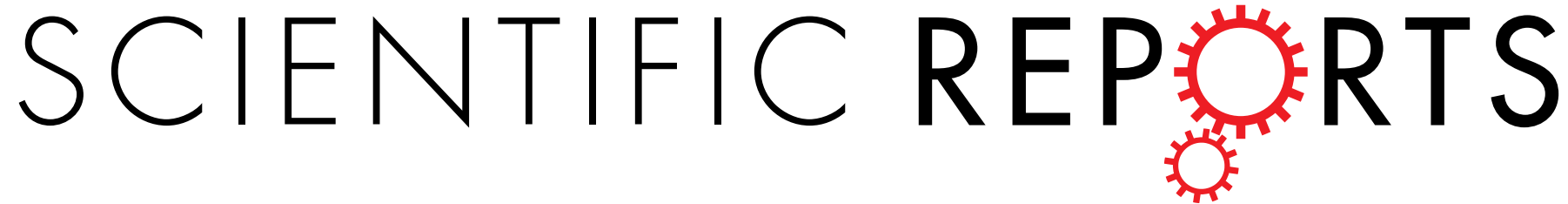

OPEN

\title{
Fish hosts, glochidia features and life cycle of the endemic freshwater pearl mussel Margaritifera dahurica from the Amur Basin
}

Ilya V. Vikhrev $\mathbb{1}^{1,2,3}$, Alexander A. Makhrov $\mathbb{1}^{3,4}$, Valentina S. Artamonova ${ }^{3,4}$, Alexey V. Ermolenko ${ }^{5}$, MikhailY. Gofarov ${ }^{1,2}$, Mikhail B. Kabakov' ${ }^{2}$ AlexanderV. Kondakov ${ }^{1,2,3}$, Dmitry G. Chukhchin ${ }^{1}$, Artem A. Lyubas ${ }^{1,2}$ \& Ivan N. Bolotov $\mathbb{1}^{1,2,3}$

Margaritiferidae is a small freshwater bivalve family with 16 species. In spite of a small number of taxa and long-term history of research, several gaps in our knowledge on the freshwater pearl mussels still exist. Here we present the discovery of host fishes for Margaritifera dahurica, i.e. Lower Amur grayling, sharp-snouted lenok, and blunt-snouted lenok. The host fishes were studied in rivers of the Ussuri Basin. The identification of glochidia and fish hosts was confirmed by DNA analysis. The life cycle of $M$. dahurica and its glochidia are described for the first time. The SEM study of glochidia revealed that the rounded, unhooked Margaritifera dahurica larvae are similar to those of the other Margaritiferidae. Margaritifera dahurica is a tachytictic breeder, the larvae of which attach to fish gills during the Late August - September and finish the metamorphosis in June. Ancestral host reconstruction and a review of the salmonid - pearl mussel coevolution suggest that the ancestral host of the Margaritiferidae was a non-salmonid fish, while that of the genus Margaritifera most likely was an early salmonid species or their stem lineage. The overfishing of lenoks and graylings appears to be the most significant threat for this rare mussel species.

The study of parasites and hosts which have been connected to each other for tens of million years contributes significantly to our understanding of the evolutionary process ${ }^{1-4}$. A remarkable example of such associated species is presented in freshwater environments, in which freshwater mussels of the order Unionida (Bivalves) and fishes are closely connected to each other. Unionida, or naiades, use fishes as hosts for their larva (glochidium) during the parasitic stage. Our knowledge on the mussel-fish interactions is far from being complete, because host fishes of many mussel species are still unknown ${ }^{5}$. Such a knowledge gap leads to underestimating the role of fish in mussel conservation ${ }^{6}$ and hampers the development of effective mussel conservation strategies.

The freshwater pearl mussels (Margaritiferidae) is a small freshwater bivalve family with only 16 species $^{7}$ but for less than half of these species the fish hosts are known. For instance, data on the hosts of Margaritifera dahurica (Middendorff, 1850), Pseudunio homsensis (Lea, 1865), P. marocanus (Pallary, 1918), and all five representatives of the genus Gibbosula Simpson, 1900 is absent or insufficient ${ }^{7-11}$. The identification of hosts is highly important for conservation of freshwater pearl mussels which are keystone species and ecosystem engineers in freshwaters. As other naiads, freshwater pearl mussels directly impact benthic processes as they burrow through sediments and ensure deposition of nutrients as filter feeders ${ }^{12,13}$.

One of the causes of freshwater pearl mussel population decline is the decreasing of abundance or local extinction of host fishes ${ }^{14-19}$. M. dahurica is listed in "The IUCN Red List of Threatened Species" under the "Data Deficient" category ${ }^{20}$. It means that reliable data on the population trends and abundance of this species is yet to be obtained. Our limited knowledge on the ecology and biology of $M$. dahurica enables to estimate possible

${ }^{1}$ Northern Arctic Federal University, Arkhangelsk, 163002, Russia. ${ }^{2}$ Federal Center for Integrated Arctic Research, Russian Academy of Sciences, Arkhangelsk, 163000, Russia. ${ }^{3}$ Saint-Petersburg State University, Saint-Petersburg, 199034, Russia. ${ }^{4}$ A.N. Severtsov Institute of Ecology and Evolution, Russian Academy of Sciences, Moscow, 119071, Russia. ${ }^{5}$ Federal Scientific Center of the East Asia Terrestrial Biodiversity, Far Eastern Branch of the Russian Academy of Sciences, Vladivostok, 690022, Russia. Correspondence and requests for materials should be addressed to I.V.V. (email: vikhrevilja@gmail.com) 


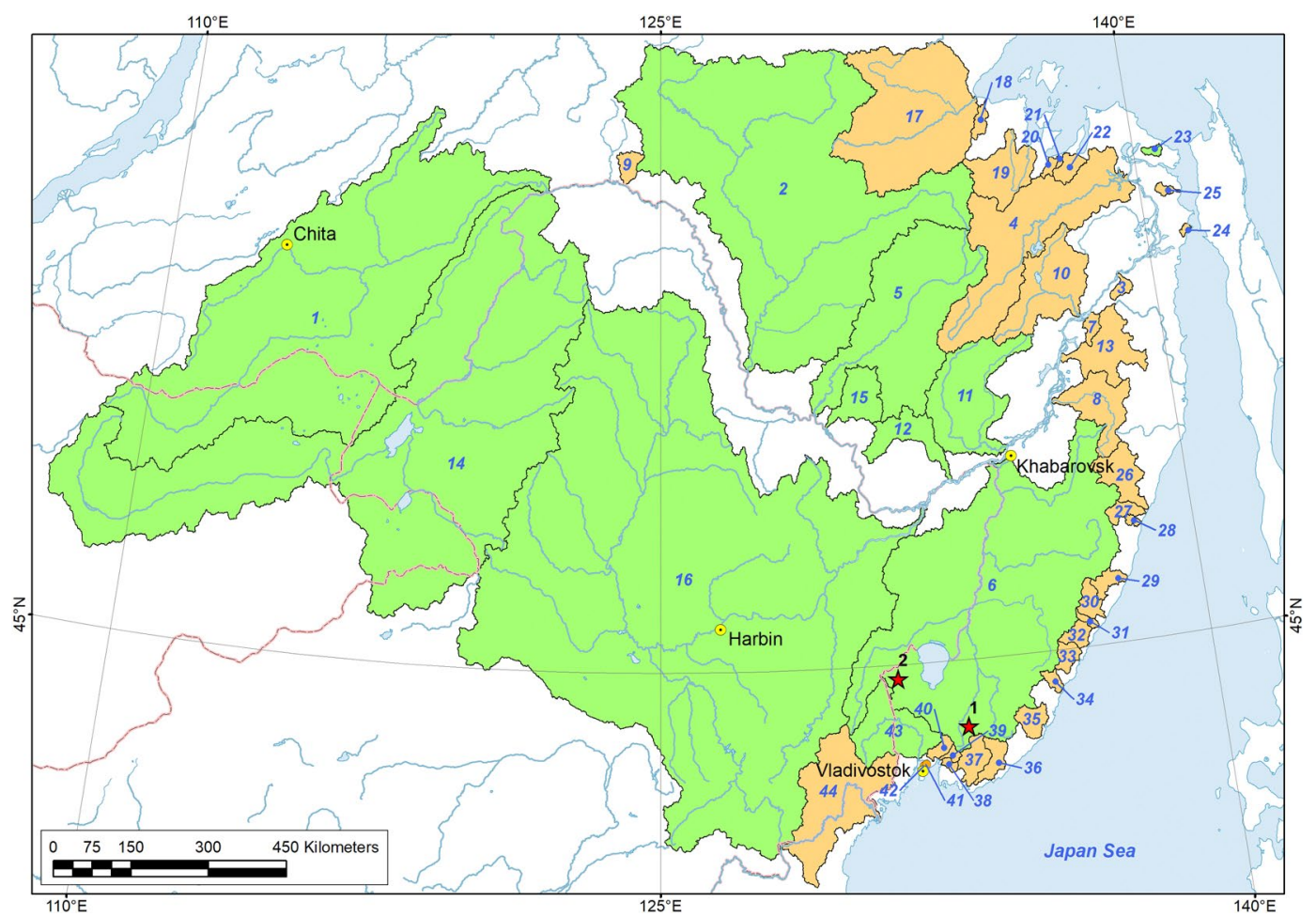

Figure 1. Distribution map of Margaritifera dahurica and its host fish genus Brachymystax in the Russian Far East. Blue numbers correspond to certain river basins (Supplementary Table 3). Green filling indicates co-occurrence of both the mussel and the host, and yellow filling indicates freshwater basins, in which only Brachymystax populations were recorded. Red asterisks indicate sites from which fish host samples were collected: (1) Muraveika River (tributary of the Ussuri River), and (2) Komissarovka River (tributary of the Khanka Lake). The map has been created using ESRI ArcGIS 10 software (www.esri.com/arcgis). The base of the map has been compiled from free open sources such as Natural Earth Free Vector and Raster Map Data (http://www. naturalearthdata.com), Global Self-consistent Hierarchical High-resolution Geography, GSHHG (http://www. soest.hawaii.edu/pwessel/gshhg), HydroSHEDS (Lehner, B., Verdin, K., Jarvis, A. (2008): New global hydrography derived from spaceborne elevation data. Eos, Transactions, AGU, 89(10): 93-94), and GADM (Global Administrative Areas (2012). GADM database of Global Administrative Areas, version 2.0. www.gadm.org).

threats correctly. For example, a relatively low number of juvenile mussels was recorded in several populations of M. dahurica ${ }^{21}$, but reasons for this phenomenon are yet to be studied.

M. dahurica ranges throughout the Amur River basin in the Russian Far East and China, and several adjacent separate rivers of the Okhotsk and Japan Sea drainages (Fig. 1). A single old record notes the occurrence of "M. margaritifera" in the north of the Korean Peninsula, but it is probably a misidentification of M. dahurica ${ }^{22}$, because distribution of M. margaritifera (Linnaeus, 1758) in Eurasia is restricted to Europe. The fish hosts of M. dahurica are yet to be discovered. Klishko and Bogan ${ }^{23}$ listed seven salmonid species in the Amur River drainage which could be the potential hosts for glochidia of this freshwater pearl mussel species. Masu Salmon Oncorhynchus masou (Brevoort, 1856) was suggested as a potential host in the Komarovka River (Razdolnaya Basin) ${ }^{24}$. Lenok or Manchurian trout Brachymystax lenok (Pallas, 1773) was observed to be infested by glochidia in the Komissarovka River (tributary of the Khanka Lake, Amur Basin) but the larvae were not identified with certainty ${ }^{9}$. The unknown reproductive timing of $M$. dahurica make the task of host identification complicated. Mussels use two basic reproductive strategies: bradytictic (long-term breeders) and tachytictic (short-term breeders) (Ortmann, 1919). Mussels with a bradytictic strategy spawn eggs to marsupia in the late summer, develop larvae during the fall and overwinter glochidia in the marsupia. Tachytictic breeders fertilize eggs during summer, and fully developed glochidia release from a host in the late summer or fall of the same year. Most of freshwater pearl mussels are tachytictic breeders, e.g. Margaritifera margaritifera ${ }^{24}$, M. laevis (Haas, 1910) ${ }^{25}$, M. middendorffi (Rosén, 1926) $)^{26}$, M. falcata (Gould, 1850) ${ }^{27,28}$, M. hembeli (Conrad, 1838) ${ }^{29}$ and Pseudunio auricularius $\left(\right.$ Spengler, 1793) ${ }^{30}$. Cumberlandia monodonta (Say, 1829) is the only example of a biannual spawner within the family ${ }^{31}$. However, for each breeding strategy the timing of life cycle stages is temperature dependent and can vary even within a species. For example, Bauer reported a M. margaritifera population in Germany, in which juvenile mussels leave a host in autumn, while in another population glochidia overwinter on a host ${ }^{32}$. The life cycle of $M$. dahurica is almost completely unstudied. However, it was reported that $M$. dahurica from the Ingoda River, Transbaikalia, Russia, starts to release glochidia when the water temperature become lower than $8-10^{\circ} \mathrm{C}$, which takes place at the end of September in the area ${ }^{33}$. 
A

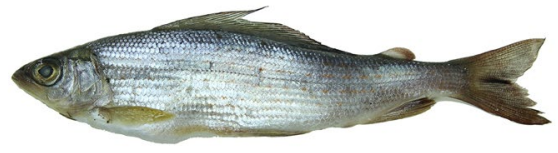

B
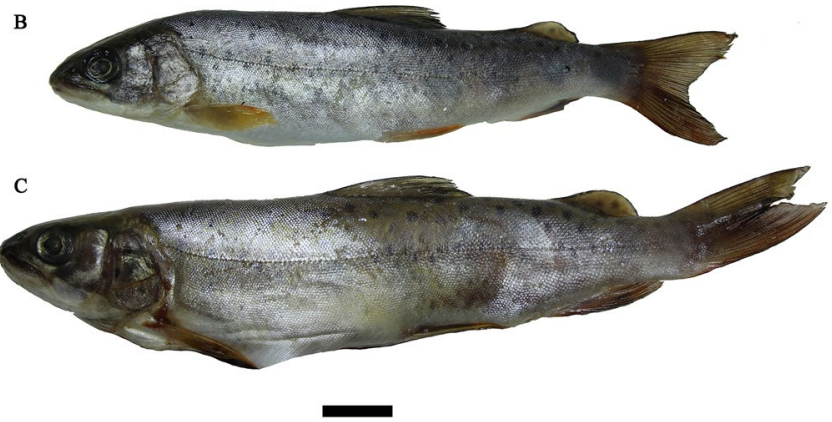

Figure 2. Hosts of Margaritifera dahurica, Komissarovka River, Khanka Lake Basin, March 2017, local fisherman leg. (A) Lower Amur grayling Thymallus tugarinae. (B) Sharp-snouted lenok Brachymystax lenok. (C) Blunt-snouted lenok B. tumensis. Scale bar $=20 \mathrm{~mm}$. (Photos: Ilya V. Vikhrev).

M. dahurica is the only species within the genus, the fish hosts of which are still unknown. Its nearest neighbor, M. margaritifera, use Salmonidae as a host for glochidia, like most of Margaritifera species ${ }^{7}$. It is logical to suppose that the larvae of $M$. dahurica also use salmonids as hosts. The lack of those data is the last white spot in our knowledge on fish hosts of freshwater pearl mussels parasitizing on salmonids. In the absence of these data general patterns of coevolution of freshwater pearl mussels and salmonids are debatable ${ }^{24}$ and cannot be resolved.

The aim of the present study is to describe the life cycle of $M$. dahurica and to improve our understanding of coevolution of the freshwater pearl mussels and their hosts. For this purpose, we: (1) identify the fish hosts of $M$. dahurica; (2) describe the morphology of the glochidium stage; (3) estimate reproductive timing of $M$. dahurica; and (4) reconstruct ancestral fish hosts for the freshwater pearl mussels on the basis of statistical approaches and multi-locus phylogeny.

\section{Results}

Discovery of fish hosts. Ten specimens of Lower Amur grayling Thymallus tugarinae Knizhin, Antonov, Safronov \& Weiss, 2007 and one specimen of blunt-snouted lenok Brachymystax tumensis Mori, 1930 were caught in May 2017 in the Muraveika River, a tributary of the Ussuri River, Russian Far East (Fig. 1). Another two fish samples were collected in a small tributary of the Komissarovka River (tributary of the Khanka Lake) (Figs 1, 2). The first sample was caught in March 2017 and it contained eighteen sharp-snouted lenoks Brachymystax lenok, seven blunt-snouted lenoks, and one Lower Amur grayling. The second sample was caught in May 2017 and it contained eight blunt-snouted and three sharp-snouted lenoks. Two Lower Amur graylings were caught in another small unnamed tributary of the Komissarovka River. Both tributaries are close to each other.

Gills of all sampled fishes were examined for glochidia. The glochidia were identified using light microscopy on one of the ten Lower Amur graylings from the Muraveyka River, and on one of the three Lower Amur graylings from a tributary of the Komissarovka River. Both of these identifications were checked and confirmed by the DNA analyses (Table 1). Every lenok, that was caught in March 2017, was infested by glochidia according to the light microscopy investigation but was not checked by the DNA analysis. Among eleven lenoks caught in May 2017 in a tributary of the Komissarovka River, glochidia were identified, using light microscopy, on six fishes, i.e. on four blunt-snouted lenoks and two sharp-snouted lenoks. All these identifications were checked by the DNA analysis and the presence of glochidia was confirmed for five fishes. Glochidia on the sixth fish were recorded by microscopy, but the DNA identification was failed, likely due to a low number of the larvae. Encysted glochidia were attached to gill filaments and clearly visible on a fresh material (Fig. 3A). The COI and cyt-b partial sequences of infested fishes were examined to confirm species identification.

Molecular identification of glochidia. DNA barcoding of glochidia observed on the fish gills reveals that Lower Amur grayling, sharp-snouted lenok and blunt-snouted lenok are host species for M. dahurica (Table 1). Among 11 lenoks caught in May in the Komissarovka river, infestation of 5 lenoks was confirmed with certainty thanks to the high concentration of glochidia DNA in the samples. Other fishes had a weak signal which did not allow us to say unambiguously whether it is the mussel DNA or not. Among 12 sampled Lower Amur graylings only three fishes were infested according to the DNA barcoding analysis (Table 1).

Morphological identification of glochidia. Unhooked glochidia of M. dahurica have D-shaped form with straight hinge and rounded ventral margin (Fig. 3B). The length of released glochidia (mean $57.4 \mu \mathrm{m}$, $\mathrm{SD} \pm 3.5 \mu \mathrm{m}, N=26$ ) is comparable to those in the other Margaritiferidae (Supplementary Tables 1 and 2). The glochidial surface has small depressions covering over the shell without any structures or strong sculpture. The comparison of released glochidia and glochidia at the end of metamorphosis reveals that the mean length of larvae is increasing in more than two times during the metamorphosis (Fig. 3C; Supplementary Table 2). 


\begin{tabular}{|c|c|c|c|c|c|}
\hline \multirow[b]{2}{*}{ Host fish species } & \multirow[b]{2}{*}{ Voucher no. } & \multirow[b]{2}{*}{ River } & \multirow[b]{2}{*}{$\begin{array}{l}\text { DNA barcoding of fish } \\
\text { hosts, NCBI GenBank acc. } \\
\text { no. for COI/cyt-b sequences }\end{array}$} & \multicolumn{2}{|c|}{ M. dahurica larvae } \\
\hline & & & & $\begin{array}{l}\text { Microscopic } \\
\text { investigation }\end{array}$ & $\begin{array}{l}\text { DNA barcoding, } \\
\text { NCBI GenBank } \\
\text { acc. no. }\end{array}$ \\
\hline \multicolumn{6}{|l|}{ March 2017} \\
\hline Brachymystax lenok & 2 & Komissarovka & $\mathrm{n} / \mathrm{a}$ & Abundant & $\mathrm{n} / \mathrm{a}$ \\
\hline B. lenok & 3 & Komissarovka & $\mathrm{n} / \mathrm{a}$ & Abundant & $\mathrm{n} / \mathrm{a}$ \\
\hline B. lenok & 4 & Komissarovka & $\mathrm{n} / \mathrm{a}$ & Rare & $\mathrm{n} / \mathrm{a}$ \\
\hline B. lenok & 6 & Komissarovka & $\mathrm{n} / \mathrm{a}$ & Rare & $\mathrm{n} / \mathrm{a}$ \\
\hline B. lenok & 8 & Komissarovka & $\mathrm{n} / \mathrm{a}$ & Rare & $\mathrm{n} / \mathrm{a}$ \\
\hline B. lenok & 9 & Komissarovka & $\mathrm{n} / \mathrm{a}$ & Abundant & $\mathrm{n} / \mathrm{a}$ \\
\hline B. lenok & 11 & Komissarovka & $\mathrm{n} / \mathrm{a}$ & Abundant & $\mathrm{n} / \mathrm{a}$ \\
\hline B. lenok & 12 & Komissarovka & $\mathrm{n} / \mathrm{a}$ & Rare & $\mathrm{n} / \mathrm{a}$ \\
\hline B. lenok & 13 & Komissarovka & $\mathrm{n} / \mathrm{a}$ & Abundant & $\mathrm{n} / \mathrm{a}$ \\
\hline B. lenok & 15 & Komissarovka & $\mathrm{n} / \mathrm{a}$ & Abundant & $\mathrm{n} / \mathrm{a}$ \\
\hline B. lenok & 16 & Komissarovka & $\mathrm{n} / \mathrm{a}$ & Rare & $\mathrm{n} / \mathrm{a}$ \\
\hline B. lenok & 17 & Komissarovka & $\mathrm{n} / \mathrm{a}$ & Abundant & $\mathrm{n} / \mathrm{a}$ \\
\hline B. lenok & 19 & Komissarovka & $\mathrm{n} / \mathrm{a}$ & Rare & $\mathrm{n} / \mathrm{a}$ \\
\hline B. lenok & 20 & Komissarovka & $\mathrm{n} / \mathrm{a}$ & Abundant & $\mathrm{n} / \mathrm{a}$ \\
\hline B. lenok & 21 & Komissarovka & $\mathrm{n} / \mathrm{a}$ & Abundant & $\mathrm{n} / \mathrm{a}$ \\
\hline B. lenok & 22 & Komissarovka & $\mathrm{n} / \mathrm{a}$ & Rare & $\mathrm{n} / \mathrm{a}$ \\
\hline B. lenok & 23 & Komissarovka & $\mathrm{n} / \mathrm{a}$ & Rare & $\mathrm{n} / \mathrm{a}$ \\
\hline B. lenok & 24 & Komissarovka & $\mathrm{n} / \mathrm{a}$ & Rare & $\mathrm{n} / \mathrm{a}$ \\
\hline B. tumensis & 1 & Komissarovka & $\mathrm{n} / \mathrm{a}$ & Rare & $\mathrm{n} / \mathrm{a}$ \\
\hline B. tumensis & 5 & Komissarovka & $\mathrm{n} / \mathrm{a}$ & Rare & $\mathrm{n} / \mathrm{a}$ \\
\hline B. tumensis & 7 & Komissarovka & $\mathrm{n} / \mathrm{a}$ & Rare & $\mathrm{n} / \mathrm{a}$ \\
\hline B. tumensis & 10 & Komissarovka & $\mathrm{n} / \mathrm{a}$ & Rare & $\mathrm{n} / \mathrm{a}$ \\
\hline B. tumensis & 14 & Komissarovka & $\mathrm{n} / \mathrm{a}$ & Rare & $\mathrm{n} / \mathrm{a}$ \\
\hline B. tumensis & 18 & Komissarovka & $\mathrm{n} / \mathrm{a}$ & Rare & $\mathrm{n} / \mathrm{a}$ \\
\hline B. tumensis & 25 & Komissarovka & $\mathrm{n} / \mathrm{a}$ & Rare & $\mathrm{n} / \mathrm{a}$ \\
\hline T. tugarinae & 1 & Komissarovka & $\mathrm{n} / \mathrm{a}$ & Absent & $\mathrm{n} / \mathrm{a}$ \\
\hline \multicolumn{6}{|l|}{ May 2017} \\
\hline Brachymystax lenok & gil $18 / 9$ & Komissarovka & MG951555/MK024300 & Abundant & MK024308 \\
\hline B. lenok & gil 19/7 & Komissarovka & MG951555/MK024301 & Abundant & MK024309 \\
\hline B. lenok & gil $22 / 3$ & Komissarovka & $\mathrm{n} / \mathrm{a}$ & Absent & $\mathrm{n} / \mathrm{a}$ \\
\hline B. tumensis & gil 22/4 & Komissarovka & MG951556/MK024305 & Abundant & MK024313 \\
\hline B. tumensis & gil $22 / 8$ & Komissarovka & MG951556/MK024306 & Rare & MK024314 \\
\hline B. tumensis & gil $22 / 10$ & Komissarovka & $\mathrm{n} / \mathrm{a}$ & Absent & $\mathrm{n} / \mathrm{a}$ \\
\hline B. tumensis & gil 22/1 & Komissarovka & $\mathrm{n} / \mathrm{a}$ & Absent & $\mathrm{n} / \mathrm{a}$ \\
\hline B. tumensis & gil 22/11 & Komissarovka & $\mathrm{n} / \mathrm{a}$ & Rare & $\mathrm{n} / \mathrm{a}$ \\
\hline B. tumensis & gil $17 / 2$ & Komissarovka & MG951556/MK024299 & Abundant & MK024307 \\
\hline B. tumensis & gil 22/5 & Komissarovka & $\mathrm{n} / \mathrm{a}$ & Absent & $\mathrm{n} / \mathrm{a}$ \\
\hline B. tumensis & gil 22/6 & Komissarovka & $\mathrm{n} / \mathrm{a}$ & Absent & $\mathrm{n} / \mathrm{a}$ \\
\hline B. tumensis & gil 20/2 & Muraveika & MG951557/n/a & Absent & $\mathrm{n} / \mathrm{a}$ \\
\hline Thymallus tugarinae & gil 20/3 & Muraveika & n/a/MK024302 & Rare & MK024310 \\
\hline T. tugarinae & gil 20/4 & Muraveika & $\mathrm{n} / \mathrm{a}$ & Absent & $\mathrm{n} / \mathrm{a}$ \\
\hline T. tugarinae & gil 20/5 & Muraveika & $\mathrm{n} / \mathrm{a}$ & Absent & $\mathrm{n} / \mathrm{a}$ \\
\hline T. tugarinae & gil 20/6 & Muraveika & $\mathrm{n} / \mathrm{a}$ & Absent & $\mathrm{n} / \mathrm{a}$ \\
\hline T. tugarinae & gil 20/7 & Muraveika & $\mathrm{n} / \mathrm{a}$ & Absent & $\mathrm{n} / \mathrm{a}$ \\
\hline T. tugarinae & gil 20/8 & Muraveika & $\mathrm{n} / \mathrm{a}$ & Absent & $\mathrm{n} / \mathrm{a}$ \\
\hline T. tugarinae & gil 20/9 & Muraveika & $\mathrm{n} / \mathrm{a}$ & Absent & $\mathrm{n} / \mathrm{a}$ \\
\hline T. tugarinae & gil 20/10 & Muraveika & $\mathrm{n} / \mathrm{a}$ & Absent & $\mathrm{n} / \mathrm{a}$ \\
\hline T. tugarinae & gil 20/11 & Muraveika & $\mathrm{n} / \mathrm{a}$ & Absent & $\mathrm{n} / \mathrm{a}$ \\
\hline T. tugarinae & gil 20/12 & Muraveika & n/a/MK024303 & Absent & MK024311 \\
\hline T. tugarinae & gil 21/1 & Komissarovka & n/a/MK024304 & Rare & MK024312 \\
\hline T. tugarinae & gil $21 / 2$ & Komissarovka & MG951555/MK024300 & Absent & $\mathrm{n} / \mathrm{a}$ \\
\hline
\end{tabular}

Table 1. Summary of DNA barcoding and morphological investigation of Margaritifera dahurica hosts and glochidia from tributaries of the Ussuri river basin [6]*.*River basin numbers given in brackets correspond to those in Fig. 1 and Supplementary Table 3. n/a - Not available. 

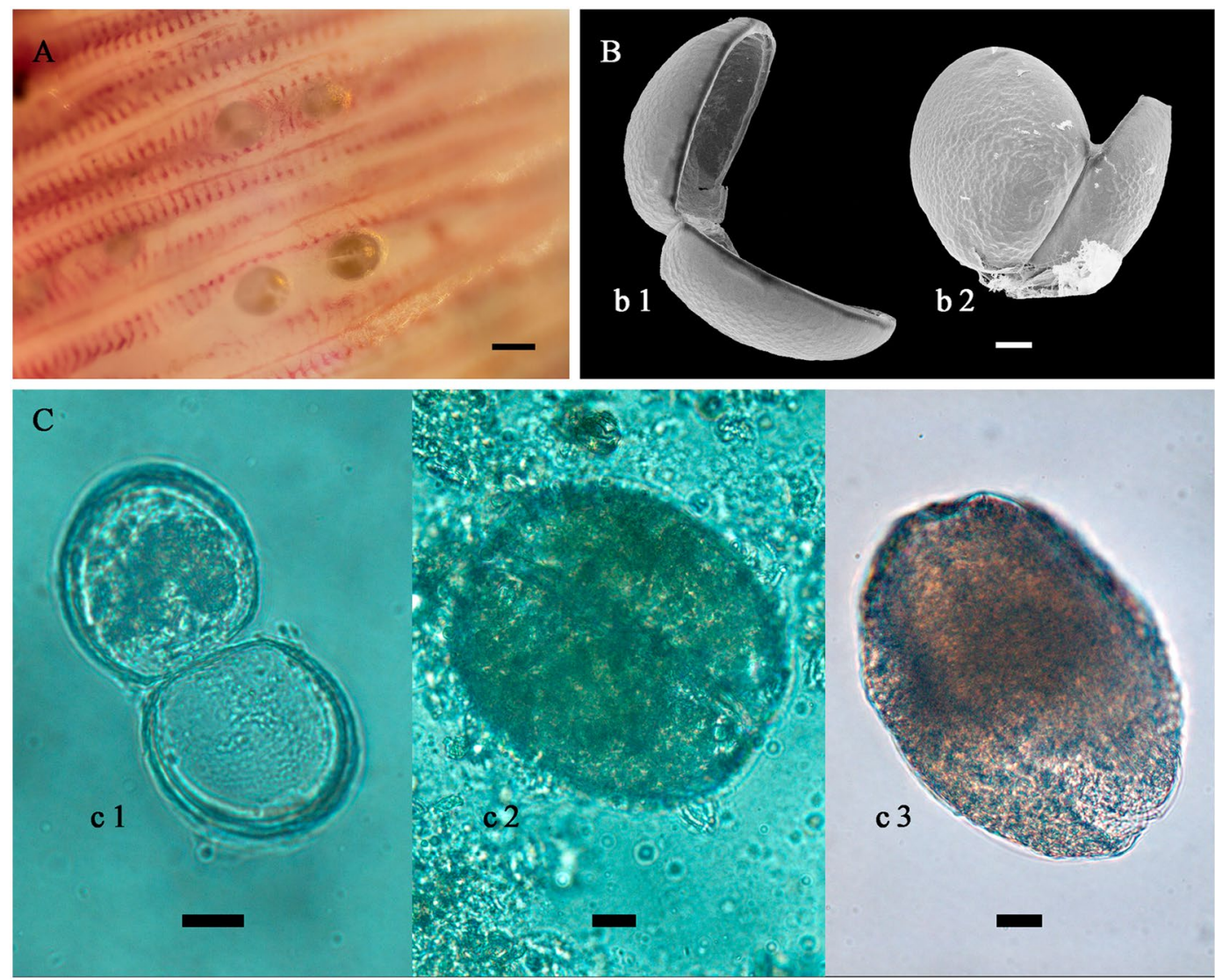

Figure 3. Morphology and growth of Margaritifera dahurica glochidia. (A) Glochidia on gills of Brachymystax lenok, Komissarovka River, 24 May 2017 (scale bar $=100 \mu \mathrm{m}$ ). (B) SEM microphotographs of glochidia, Tyrma River, Amur Basin, Eastern Siberia, 31 August 2015, including (b1) lateral view, and (b2) dorsal view (scale bar $=10 \mu \mathrm{m})$. (C) Glochidia during metamorphosis, including (c1) at the end of August (right after releasing), (c2) at March, and (c3) at Late May (scale bars $=20 \mu \mathrm{m})$. (Photos: Ilya V. Vikhrev [A, C] and Dmitry G. Chukhchin $[\mathrm{B}])$

Life cycle of Margaritifera dahurica. General scheme of the life cycle of $M$. dahurica is very similar to that of M. margaritifera (Fig. 4; Table 2). The glochidia of the latter are discharged into a river in mid- to late summer and developed in the host gills for a period up to 10 months $^{34}$. Mature M. dahurica collected in the mid-July had empty marsupia. Aborted glochidia were collected at the end of August from the individuals that were disturbed during measurements, which means that specimens were ready to release glochidia in the nearest future. Encysted glochidia were observed in both fish samples from March and May. Some of glochidia registered in March were of similar size as free-living larvae after releasing from mussels, and others were up to four times larger. Glochidia observed at the end of May have had less variable length from $89.4 \mu \mathrm{m}$ to $189.1 \mu \mathrm{m}$ ( $\min$-max values). We found significant size differences between the samples of glochidia collected in September, March and May (Kruskal-Wallis test: $\mathrm{H}=57.4, \mathrm{p}<0.0005$ ) with the mean length of $57.4 \mu \mathrm{m}, 92.2 \mu \mathrm{m}$ and $150.7 \mu \mathrm{m}$, correspondingly.

Distribution range of Margaritifera dahurica and its hosts. A review of the body of literature shows that the distribution range of M. dahurica ${ }^{35}$ fully agrees with those of lenoks (Fig. 1, Supplementary Table 3). The two lenok species have been recognized as two different species recently, and we therefore cannot compare the distribution of $M$. dahurica and every of the two lenok species separately. The lenoks were observed in all the regions in which $M$. dahurica was recorded (Fig. 1, Supplementary Table 3). These fishes inhabit the Amur River drainage within the Russian territory ${ }^{36,37}$, China $^{38}$ and Mongolia ${ }^{39}$. The lenoks were also recorded in rivers of the southern part of the Okhotsk Sea coast and the Russian part of the Japan Sea coast ${ }^{40,41}$, e.g. in the Razdolnaya River ${ }^{42}$.

Ancestral host reconstruction. Our Bayesian Markov chain Monte Carlo (MCMC) modeling suggests that the ancestral host of the Margaritiferidae was a non-salmonid fish (probability $=98.9 \%$ ) (Fig. 5). In contrast, the ancestral host of the genus Margaritifera most likely was an early salmonid species or their stem lineage (probability $=97.8 \%$ ). The hypotheses of salmonid hosts of the most recent common ancestor (MRCA) of M. margaritifera + M. dahurica subclade and of the "Pacific" subclade were also fully supported by this 


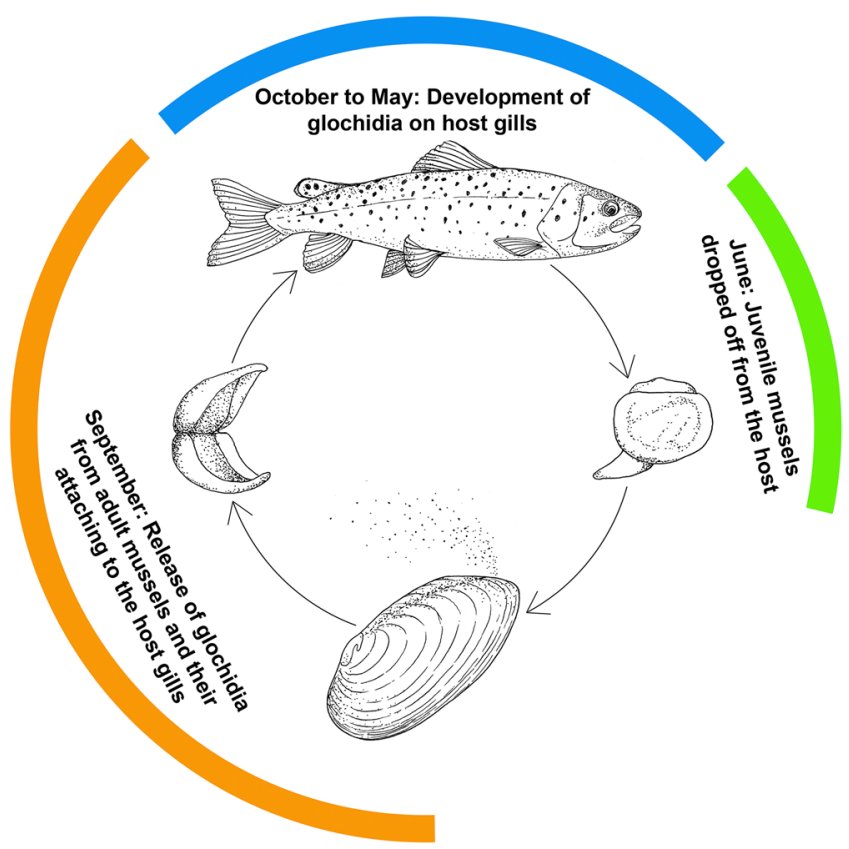

Figure 4. Simplified scheme of Margaritifera dahurica life cycle (See details of field observations in Table 2). The host fish are Brachymystax lenok, B. tumensis and Thymallus tugarinae. (Graphics: Inga S. Paltser).

\begin{tabular}{|l|l|l|l|l|}
\hline River* & Drainage & Date & Observations & Life cycle stage \\
\hline Ussury River [6] & Amur River & 20 July 2012 & Empty marsupia & $\begin{array}{l}\text { Eggs maturation in } \\
\text { gonades }\end{array}$ \\
\hline Tyrma River [5] & Amur River & 31 August 2015 & $\begin{array}{l}\text { Mature glochidia in marsupia and } \\
\text { glochidia releasing from disturbed mussels }\end{array}$ & $\begin{array}{l}\text { Mussels are ready to } \\
\text { release glochidia }\end{array}$ \\
\hline Ingoda River [1]** & Ditto & End of September & Ditto & Ditto \\
\hline $\begin{array}{l}\text { A tributary of the } \\
\text { Komissarovka River [6] }\end{array}$ & $\begin{array}{l}\text { Khanka } \\
\text { Lake=>Amur River }\end{array}$ & March 2017 & $\begin{array}{l}\text { Glochidia of different size on the host gills: } \\
\text { difference between the smallest and the } \\
\text { biggest larva is more than four times }\end{array}$ & Growth of glochidia \\
\hline $\begin{array}{l}\text { A tributary of the } \\
\text { Komissarovka River [6] }\end{array}$ & $\begin{array}{l}\text { Khanka } \\
\text { Lake=>Amur River }\end{array}$ & 25 May 2017 & $\begin{array}{l}\text { Glochidia on the host gills: still different } \\
\text { in size, but difference between the smallest } \\
\text { and the biggest larva is around two times }\end{array}$ & $\begin{array}{l}\text { Glochidia near to the } \\
\text { end of metamophosis }\end{array}$ \\
\hline
\end{tabular}

Table 2. Field observations of life cycle of Margaritifera dahurica and comparison of glochidia release timing in the northern and southern parts of the range. *River basin numbers given in brackets correspond to those in Fig. 1 and Supplementary Table 3. **Published observation ${ }^{33}$.

model (probability $=100 \%$ ) (Fig. 5). The interactions of M. hembeli and M. marrianae with non-salmonid hosts appear to be a secondary adaptation derived from a common ancestor of both species in North America (probability $=98.4 \%)$.

\section{Discussion}

Morphology of glochidia and life cycle of Margaritifera dahurica. General patterns of glochidia morphology of $M$. dahurica are similar to those in the other Margaritiferidae which have unhooked, rounded, small larvae against hooked, triangular and larger larvae in the Unionidae ${ }^{43}$. Despite the close genetic relationship to $M$. margaritifera, glochidia of $M$. dahurica are morphologically more similar to the larvae of $P$. auricularius, $M$. laevis and $M$. middendorffi, due to their rounded ventral margin ${ }^{44,45}$ against the slightly more triangular ventral margin of M. margaritifera larvae ${ }^{46}$. Regarding size, the glochidia of $M$. dahurica fit well within the size range of larvae of other freshwater pearl mussels, with exception of $P$. auricularius having the largest larvae among the Margaritiferidae (Supplementary Table 1).

Our findings reveal that $M$. dahurica is a tachytictic breeder with a long-term parasitic stage which passes throughout the winter (Fig. 4). According to Klishko ${ }^{33}$, M. dahurica starts to release glochidia when water temperature drops below $8-10^{\circ} \mathrm{C}$, which occurs at the end of September in Eastern Siberia. It is well known that reproductive timing in freshwater mussels shifts depending on water temperature ${ }^{25,27,28}$. In northern regions the glochidia release starts earlier, as we observed for $M$. dahurica in the Tyrma River, north of Khabarovsky Kray (Table 2). The fact that the life cycle timing of $M$. dahurica is very similar to that of $M$. margaritifera is in agreement with the phylogenetic proximity of two species ${ }^{47}$. Representatives of the genus Thymallus have not yet been 


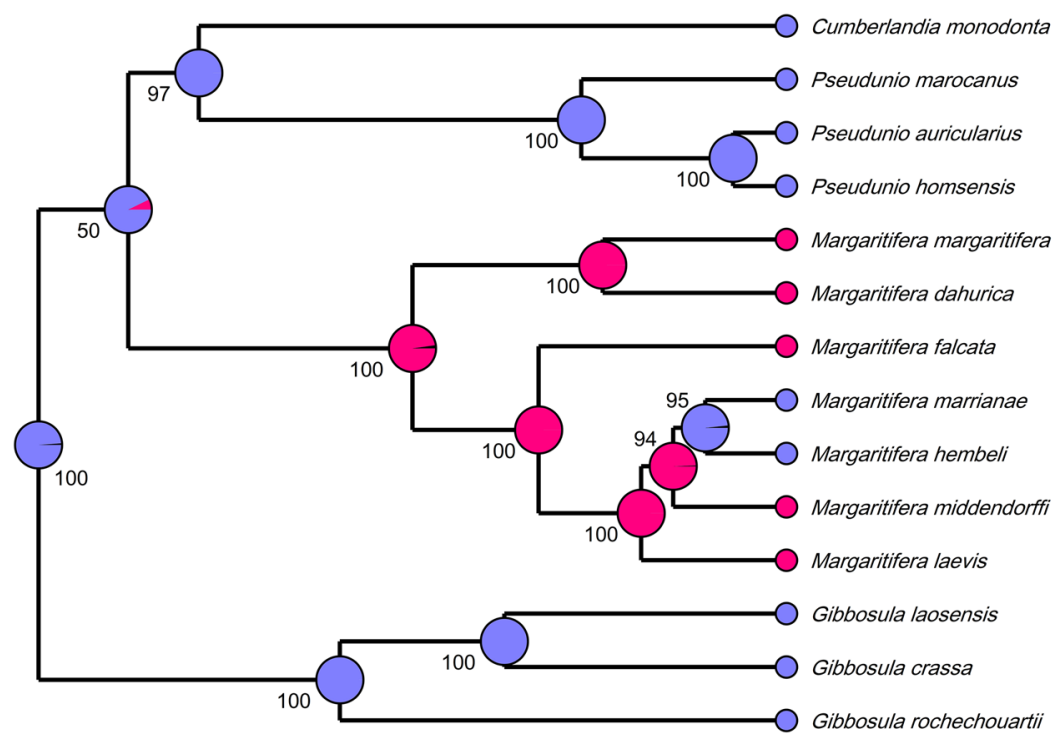

Figure 5. Ancestral host reconstruction for the Margaritiferidae on the basis of Bayesian MCMC analyses. The statistical models were calculated using a multi-locus fossil-calibrated phylogeny and fish host database of

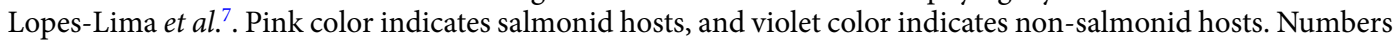
near nodes are Bayesian posterior probabilities.

considered as potential hosts for the larvae of freshwater pearl mussels. Our discovery of M. dahurica glochidia parasitizing on Thymallus tugarinae expands the current knowledge on the host range in the Margaritiferidae.

Our study describes only general patterns of the life cycle of $M$. dahurica. However, the details are still incomplete and are in need of future studies. The data such as the age of maturity, dependence between temperature and timing of juveniles drop off from the host, certain dates of life cycle stages for different regions, and testing other putative host fishes, e.g. Siberian Taimen Hucho taimen (Pallas, 1773), are of great importance for the effective conservation planning for M. dahurica.

Co-occurrence of Margaritifera dahurica and the Brachymystax species. Our results reveal that the host-parasite interaction between $M$. dahurica and lenoks corresponds well to the published data on the distribution and habitat preferences of these fish taxa (Supplementary Table 3). Sandy-gravel and gravel-pebble grounds at riffles and runs, typical habitats of the freshwater pearl mussels ${ }^{35}$, are also inhabited by lenoks ${ }^{48}$. However, lenoks share a wider distribution than $M$. dahurica. Besides the regions inhabited by the freshwater pearl mussel, these fishes are distributed in Siberia, Korean Peninsula ${ }^{49,50}$, and in several Eastern Chinese rivers ${ }^{51}$. The sharp-snouted lenok and the blunt-snouted lenok differentiated well by molecular data and morphology, i.e. shape of the head, number of gill rakers and osteological characters. Both species coexist in sympatry through the range including the Amur Basin with the Komissarovka and Myraveika rivers. Taxonomic position and phylogeny of these two lenok forms are actively discussed ${ }^{41,52-57}$, however we consider blunt- and sharp-snouted forms as two separate species based on significant genetic differences even in sympatric populations. Lenok from rivers of the Qinling Mountains, belonging to the Yangtze and Yellow River basins in China, was initially described as the subspecies Brachymystax lenok tsinlingensis Li, 1966, but was recently elevated to the species level based on molecular data ${ }^{58}$. This taxon also inhabits south of the Korean Peninsula ${ }^{50}$.

Coevolution of salmonid fishes and freshwater pearl mussels. Fossil records indicate that representatives of the family Margaritiferidae were abundant in Mesozoic water bodies of Southern Laurasia ${ }^{7,47}$ and in the north of modern Africa ${ }^{59,60}$. Meanwhile, it is considered that salmonids originated not earlier than in the Cenozoic era ${ }^{61,62}$, and Mesozoic freshwater pearl mussels, most likely, used other hosts, like the recent Margaritiferidae from southern regions (Table 3 and Fig. 5).

The most ancient fossil representatives of the genus $\dagger$ Eosalmo (earliest known salmonids), that were found in British Columbia ${ }^{62}$ and Kamchatka ${ }^{61}$, document that ancient salmonids existed in the northern part of the Pacific Ocean drainage in the Eocene. This record corresponds well with the time of appearance of freshwater pearl mussels in the region. These mussel taxa appeared at the northern coast of the Pacific Ocean for a first time near the Paleocene - Eocene boundary ${ }^{7} \dagger$ Margaritifera herrei (Hannibal, 1912) was spread in waterbodies located on the territory of the modern California ${ }^{63}$, while $\uparrow M$. perdahurica (Yokoyama, 1932), $\uparrow M$. otatumei (Suzuki, 1942) and $\dagger$. owadaensis Noda, 1970 inhabited territory of the modern Hokkaido Island ${ }^{47}$. Ziuganov et al. ${ }^{24}$ hypothesized that spreading of freshwater pearl mussels across the northern part of the Pacific drainages was likely related to the adaptation to parasitizing on salmonids.

During the mid-Eocene epoch ( 42 Ma), freshwater pearl mussels appeared on the territory of the modern Yakutia, and then spread further to the west and south ${ }^{7}$. Moving southward, at the mid-Oligocene $(\sim 28 \mathrm{Ma})$, freshwater pearl mussels colonized the area of the modern Aral Sea and southeast shore of Lake Baikal. These freshwater pearl mussels were considered to be a single species, $\uparrow$ M. martinsoni Modell, 1964 ${ }^{47}$. Remarkably, 


\begin{tabular}{|c|c|}
\hline Mussel species & Fish hosts \\
\hline Margaritifera dahurica & $\begin{array}{l}\text { Salmonidae: sharp-snouted lenok (Brachymystax lenok), blunt-snouted lenok (B. tumensis), } \\
\text { and Lower Amur grayling (Thymallus tugarinae) [this study] }\end{array}$ \\
\hline Margaritifera margaritifera & $\begin{array}{l}\text { Salmonidae: Atlantic salmon (Salmo salar), brown trout (S. trutta), Arctic charr (Salvelinus } \\
\text { alpinus), brook trout (S. fontinalis) (high susceptible host in North America but less } \\
\text { susceptible or even an unsuitable host fish in Europe), and Danube salmon (Hucho hucho) } \\
\text { (less susceptible host) })^{7,24,68,90,91}\end{array}$ \\
\hline Margaritifera falcata & $\begin{array}{l}\text { Salmonidae: Chinook salmon (Oncorhynchus tshawytscha), Coho salmon (O. kisutch), } \\
\text { cutthroat trout (Parasalmo clarki), and steelhead trout (P. mykiss); Gasterosteidae: three- } \\
\text { spined stickleback (Gasterosteus aculeatus) }\end{array}$ \\
\hline Margaritifera hembeli & Esocidae $^{7}$ \\
\hline Margaritifera marrianae & Esocidae $^{7}$ \\
\hline Margaritifera laevis & Salmonidae: Masu salmon (Oncorhynchus masou) ${ }^{25,45,93,94}$ \\
\hline $\begin{array}{l}\text { Margaritifera middendorffi } \\
(=\text { M. togakushiensis) }\end{array}$ & Salmonidae: White-spotted char (Salvelinus leucomaenis) ${ }^{95}$ \\
\hline Cumberlandia monodonta & Hiodontidae: Mooneye (Hiodon tergisus) and Goldeye $\left(\right.$ H. alosoides) ${ }^{96}$ \\
\hline Pseudunio auricularius & $\begin{array}{l}\text { Acipenseridae: sturgeons (Acipenser spp.); Blenniidae: River blenny (Salaria fluviatilis); } \\
\text { Gasterosteidae: Three-spined stickleback (Gasterosteus aculeatus) }\end{array}$ \\
\hline Pseudunio homsensis & Unknown but surely non-salmonids (according to the distribution range) ${ }^{100}$ \\
\hline Pseudunio marocanus & Unknown, probably non-salmonids [M. Lopes-Lima, pers. comm. 2018] \\
\hline Gibbosula laosensis & Unknown but surely non-salmonids (according to the distribution range) ${ }^{14}$ \\
\hline Gibbosula crassa & Unknown but surely non-salmonids (according to the distribution range) ${ }^{7}$ \\
\hline Gibbosula rochechouartii & Unknown but surely non-salmonids (according to the distribution range and habitats) ${ }^{11}$ \\
\hline Gibbosula confragosa & Unknown $^{7}$ \\
\hline Gibbosula polysticta & Unknown $^{7}$ \\
\hline
\end{tabular}

Table 3. Review of suitable hosts of the freshwater pearl mussels (Margaritiferidae).

Brachymystax representatives appeared in paleontological records in the Upper Oligocene, e.g. $\dagger$ B. bikinensis Sytchevskaya, 1986 was discovered in the Ussuri River drainage ${ }^{61}$. Today, lenoks still inhabit the rivers of Yakutia ${ }^{53}$ and the Baikal Lake Area ${ }^{39}$. Therefore, it is likely that lenoks were hosts of glochidia of M. martinsoni. The fact that endemic trout (Salmo trutta oxianus Kessler, 1874) inhabits the Aral Sea drainage ${ }^{64}$, can be an indirect evidence that ancestors of the genus Salmo might be possible hosts for the larvae of M. martinsoni in this area. The data on the distribution of M. martinsoni and its putative host fish supports the hypothesis that this fossil taxon could be considered the MRCA of M. dahurica and M. margaritifera ${ }^{47}$.

As it has been shown recently, M. dahurica forms a subclade together with M. margaritifera, which is distinct from a subclade containing the other freshwater pearl mussel species from the Pacific Ocean drainage ${ }^{7,47,59}$. The origin of $M$. margaritifera cannot be tracked by available paleontological data. However, Chepalyga ${ }^{65}$ suggested that the fossil species $\uparrow M$. arca Chepalyga, 1965, described from the Upper Pliocene of the Dniester and Danube river valleys, can be an ancient stem lineage of $M$. margaritifera.

The primary hosts of M. margaritifera are Atlantic salmon Salmo salar Linnaeus 1758, brown trout Salmo trutta Linnaeus 1758, and Arctic charr Salvelinus alpinus (Linnaeus 1758) (Table 3). Like $\dagger M$. arca, representatives of the genus Salmo also appeared in paleontological records in the Late Pliocene - Pleistocene. For example, $\dagger$ Salmo derzhavini Vladimirov, 1946 inhabited the territory of the modern Armenia ${ }^{66}$. Likely, ancestors of $M$. margaritifera migrated to Europe together with ancestors of Salmo or Hucho, distributed in Europe, Siberia, and the Far East of Russia. However, Hucho appeared in Europe much earlier than $† M$. arca, i.e. in the late Miocene ${ }^{67}$. Moreover, the Danube salmon Hucho hucho (Linnaeus, 1758) was recorded as a least suitable host of M. margaritifera glochidia ${ }^{68}$. At the same time, Siberian Taimen $H$. taimen can be considered a potential host for the larvae of M. dahurica as far as taimens are close to lenoks by morphological and molecular data ${ }^{41}$. Balakirev et al.$^{69}$ even recorded a genetic introgression between these two genera. However, this hypothesis needs to be confirmed by means of an experimental approach.

Numerous studies are dedicated to investigation of molecular phylogeny of salmonids, in particular evolutionary interactions between the genera Brachymystax, Hucho, and Salmo ${ }^{70}$. Osinov and Lebedev ${ }^{71}$, using a large dataset of protein-coding genes, revealed that Brachymystax, Hucho and Salmo belong to the same clade. An analysis of amino acid partial sequences of the COI returned the same result ${ }^{70}$. A genetic proximity of $M$. margaritifera and $M$. dahurica may be evidence of close evolutionary relations of their host-fishes, and correspond well to the findings of Osinov and Lebedev ${ }^{71}$ and Artamonova et al. ${ }^{70}$.

Implications for conservation of Margaritifera dahurica and salmonids in the genus Brachymystax. Most populations of $M$. dahurica inhabit clean mountain rivers in remote areas where sources of industrial, agricultural and recreational pollution are still lacking. Shell and pearl harvesting from $M$. dahurica's was praticed in the IX-V centuries $\mathrm{BC}^{72,73}$, but was prohibited in Russia in $1964^{74}$. Nowadays only illegal harvesting occurs occasionally in small amounts (personal observations). River damming bears a potential risk for several populations, but this threat requires additional research. Parasitizing of bitterling (Rhodeus sericeus (Pallas, 1776), Cyprinidae) embryos in gills of $M$. dahurica was mentioned among biological threats for this mussel species ${ }^{23}$. 
Now that, hosts of glochidia of $M$. dahurica have been discovered, it has become became clear that one of the main threats for this species is population decline of the Brachymystax species. Brachymystax lenok is listed as an endangered species in the "Red List of China's Vertebrates" 75 , and as a vulnerable species in the "Mongolian Red List of Fishes"76 and "Korean Red List of Threatened Species"77. A few populations are listed in the "Red Data Book of the Russian Federation"78 under the "endangered group of populations" category. All these red lists unite blunt- and sharp-snouted lenoks under the name Brachymystax lenok. Declines in the abundance of lenoks due to overfishing, water pollution and environmental changes ${ }^{79}$, in particular, destruction of their natural habitats caused by channel improvement ${ }^{77}$, was recorded in China. The main threat for lenoks in rivers of Russia is illegal fishing, which is especially intensive in small rivers of the Japan Sea basin in the Primorye Region ${ }^{48}$.

Finally, artificial breeding of lenoks is well developed at the present time ${ }^{80-82}$. We suggest that the artificial breeding of $M$. dahurica at fish hatcheries together with lenoks can be a possible approach for the future conservation of this freshwater pearl mussel species.

\section{Methods}

Data sampling. Glochidia were collected prior to the start of metamorphosis, right after release from mussels that were disturbed during measurements in the Tyrma River (Amur Basin) near the Tyrma settlement $\left(50.0159^{\circ} \mathrm{N}, 132.1271^{\circ} \mathrm{E}\right)$ on 31 August 2015 and fixed in $96 \%$ ethanol. Sampling of the prospective host fishes was performed in March and at the end of May 2017 in the Muraveika River (Ussuri Basin) near the Elovka village $\left(43.8432^{\circ} \mathrm{N}, 133.2160^{\circ} \mathrm{E}\right)$ and in two tributaries of the Komissarovka River (Khanka Lake Basin) near the Barabash-Levada village $\left(44.7641^{\circ} \mathrm{N}, 131.4217^{\circ} \mathrm{E}\right)$. Rivers are located in the Primorye Region, Russian Far East. Investigated fishes were caught by a local fisherman using fishing net. Fishes that were caught in March were kept frozen until gills examination in the laboratory. Gills of every fish from all samples were examined by light microscopy. After that, a first gill arc was fixed in 5\% formaldehyde to allow counting of the number of gill rakers. The rest of the fish gills, as well as snips of fish muscle soft tissues, were fixed in 96\% ethanol for further DNA analyses. Fixed material was deposited in the collection of the Russian Museum of Biodiversity Hotspots (RMBH), Federal Center for Integrated Arctic Research, Russian Academy of Sciences, Arkhangelsk, Russia.

Species identification of fishes and glochidia by molecular analysis. Fish gills of Lower Amur grayling (Thymallus tugarinae), blunt-snouted lenok (Brachymystax tumensis) and sharp-snouted lenok (Brachymystax lenok) infested by glochidia were taken for species identification of the mussel larvae (Table 1). Samples were stored in 96\% ethanol (1:5) and DNA was extracted using the phenol/chloroform extraction procedure ${ }^{83}$. The COI partial sequences of glochidia were amplified by polymerase chain reaction (PCR) using the universal primer LCO $1490^{84}$ and our own designed primer MarMIDL-R (5'-GAAAAAATAGCCAAGTCTACAG- $\left.3^{\prime}\right)$. The primer MarMIDL-R was used to obtain a short PCR product (423 bp) that allows examination of partly degraded DNA. Fish identification was performed by amplification of the COI partial sequences using the universal primers FishF2 and FishR2 ${ }^{85}$, and cyt-b partial sequences using the universal primers Glu $\mathrm{L}$ and $\mathrm{Thr} \mathrm{H}^{86}$. Amplification was performed using $25 \mu \mathrm{l}$ of a buffer solution (Fermentas) $\left(75 \mathrm{mM}\right.$ Tris- $\mathrm{HCl}(\mathrm{pH} 8.8), 20 \mathrm{mM}\left(\mathrm{NH}_{4}\right)_{2} \mathrm{SO}_{4}, 0.1 \%$ Tween 20, and $2 \mathrm{mM} \mathrm{MgCl}$ ). The PCR mix contained approximately $200 \mathrm{ng}$ of total cellular DNA, 10 pmol of each of two (forward and reverse) primers, $200 \mu \mathrm{mol}$ of each dNTP and 0.8 units of Taq DNA polymerase (SibEnzyme Ltd., Novosibirsk, Russia). Thermocycling included the initial denaturation stage $\left(4 \mathrm{~min}\right.$ at $\left.95^{\circ} \mathrm{C}\right)$ followed by $34-38$ cycles consisting of denaturation at $95^{\circ} \mathrm{C}(50 \mathrm{sec})$, annealing at $58^{\circ} \mathrm{C}(50 \mathrm{sec})$, and extension at $72^{\circ} \mathrm{C}(50 \mathrm{sec})$ followed by a final extension step at $72^{\circ} \mathrm{C}(5 \mathrm{~min})$. Forward and reverse sequencing was performed on an automatic sequencer (ABI PRISM 3730, Applied Biosystems) using the ABI PRISM BigDye Terminator v. 3.1 reagent kit in the Institutional Collective Usage Facility "Genome" of the Institute of Molecular Biology of the Russian Academy of Sciences. The resulting sequences were checked using a sequence editor (BioEdit v. 7.2.5 ${ }^{87}$ ). The obtained sequences were compared with those from NCBI GenBank database using BLAST (www.ncbi.nlm. nih.gov).

Morphological studies of glochidia. The morphology of free-living glochidia $(N=144)$ and encysted larvae $(N=35)$ on fish gills were studied using light and scanning electron microscopy. Fresh gills with encysted glochidia were photographed with a Canon EOS 7D camera (Canon Inc., Japan) with a reversed Jupiter 37 A $70 \mathrm{~mm}$ lens (KOMZ, Russia) mounted on the top of a microscope (LOMO C1Y4.2, Russia). Preparation of the fixed glochidia for microscopy followed the general scheme described by Hoggarth ${ }^{88}$ with our modifications. Glochidial mass stored in $96 \%$ ethanol was washed by deionized water and kept at $57^{\circ} \mathrm{C}$ in a solution of $390 \mathrm{ml}$ phosphate buffer $(\mathrm{pH}=6.86)$ and $10 \mathrm{mk}$ proteinase $\mathrm{K}($ concentration $=4 \mathrm{mg} / \mathrm{ml})$. The samples were inspected every $15 \mathrm{~min}$ and removed from the thermostat when the first glochidia with open valves were observed. Thereafter glochidia were washed with deionized water and stored in $96 \%$ ethanol prior to examination. Length, height and width measurements of free-living glochidia and encysted larvae on frozen and 5\% formaldehyde fixed fish gills were performed under a light microscope (Carl Zeiss Axio Lab.A1, ZEISS, Jena, Germany) using ZEN software.

Prior to scanning electron microscopy SEM, suspended glochidia were immediately frozen at $-80^{\circ} \mathrm{C}$ and then freeze-dried. The images of the samples were obtained with a SEM Sigma VP ZEISS instrument (ZEISS, Jena, Germany) ( $10 \mathrm{kV}$, InLens detector) in the Core Facility Center "Arctic" of Northern Arctic Federal University, Arkhangelsk, Russia (unique identifier RFMEFI59417X0013). A platinum-palladium coating with a thickness up to $5 \mathrm{~nm}$ was applied to the surface by means of a Q150TES device (QUORUM) to enhance the image contrast.

Mapping of the distribution ranges. The georeferenced distribution data set of Bolotov et al..$^{35}$ was used for M. dahurica. The reliable records of two lenok species (Brachymystax tumensis and B. lenok) were collected from the body of available literature (Supplementary Table 3). The map has been created using ESRI ArcGIS 10 software (www.esri.com/arcgis). 
Ancestral host reconstruction analyses. We applied a Bayesian MCMC analysis implemented in RASP v. $3.2^{89}$. As an input tree data, we used the multi-locus fossil-calibrated phylogeny of Lopes-Lima et al. ${ }^{7}$, which was calculated on the basis of the most complete sequence data set (five markers: COI - 654 bp, $16 \mathrm{~S} r R N A-475 \mathrm{bp}$, $18 S$ rRNA - $1778 \mathrm{bp}$, $28 \mathrm{~S}$ rRNA - $307 \mathrm{bp}$, and $\mathrm{H3}-327 \mathrm{bp}$ ) sampled to date. Fish hosts of the Margaritiferidae were coded as follows: (a) non-salmonid hosts, and (b) salmonid hosts. The primary data on fish hosts has been collected from Lopes-Lima et al. ${ }^{7}$. The hosts of several species, i.e. Gibbosula laosensis (Lea, 1863), G. crassa (Wood, 1815), Pseudunio homsensis (Lea, 1865), and P. marocanus (Pallary, 1918), remain unknown. However, they most likely associated with non-salmonid fishes (Table 3), and we therefore assigned "b" code for these taxa. The analysis was computed with 500,000 generations (sampling every 100th generation) and 10 MCMC chains (temp $=0.1$ ). Null distribution and two-host combination (i.e. "ab") were not allowed. We applied a $10 \%$ burn-in to exclude the pre-convergence part of the simulation.

Literature searching. The literature review was performed by searching through the ISI Web of Knowledge and Scopus databases using the following keywords: Brachymystax lenok, Thymallus tugarinae, Amur river fish, Primorski krai fish. Since these databases do not take into account the body of literature in Russian, we also looked for Cyrillic sources in RISC (Russian Index for Scientific Citation, https://elibrary.ru). Old publications were searched in libraries collections of the Russian State Library, Zoological Institute of the Russian Academy of Sciences, Russian Federal Research Institute of Fisheries and Oceanography, and the Berg State Research Institute on Lake and River Fisheries.

\section{Data Availability}

The sequences generated under this study are available from the GenBank database. Accession numbers for each specimen are presented in Table 1. The voucher specimens and fish host samples are available in the Russian Museum of Biodiversity Hotspots (RMBH), Federal Center for Integrated Arctic Research, Russian Academy of Sciences, Arkhangelsk, Russia.

\section{References}

1. Banks, J. C. \& Paterson, A. M. Multi-host parasite species in cophylogenetic studies. In International Journal for Parasitology. https://doi.org/10.1016/j.ijpara.2005.03.003 (2005).

2. Poulin, R. \& Forbes, M. R. Meta-analysis and research on host-parasite interactions: Past and future. Evolutionary Ecology. https:// doi.org/10.1007/s10682-011-9544-0 (2012).

3. Tseng, M. \& Myers, J. H. The relationship between parasite fitness and host condition in an insect -virus system. PLoS One. https:// doi.org/10.1371/journal.pone.0106401 (2014).

4. Pilosof, S. et al. Host-parasite network structure is associated with community-level immunogenetic diversity. Nat. Commun. https://doi.org/10.1038/ncomms6172 (2014).

5. Zieritz, A. et al. Diversity, biogeography and conservation of freshwater mussels (Bivalvia: Unionida) in East and Southeast Asia. Hydrobiologia 810 (2018).

6. Modesto, V. et al. Fish and mussels: Importance of fish for freshwater mussel conservation. Fish Fish. 19, 244-259 (2018).

7. Lopes-Lima, M. et al. Expansion and systematics redefinition of the most threatened freshwater mussel family, the Margaritiferidae. Mol. Phylogenet. Evol. 127 (2018).

8. Baird, M. S. Life history of the spectaclecase, Cumberlandia monodonta Say, (Bivalvia, Unionoidea, Margaritiferidae). (Southwest Missouri State University, 2000) (1829)

9. Ermolenko, A. V., Besprozvannykh, V. V. \& Shedko, S. V. Parasite fauna of salmonid fishes (Salmonidae, Salmoniformes) of Primorski kray. (Dalnauka, 1998).

10. Williams, J. D. \& Butler, R. S. Freshwater Mussels of Florida. (The University of Alabama Press, 2014).

11. Huang, X., Wu, R., An, C., Xie, G. \& Su, J. Reclassification of Lamprotula rochechouartii as Margaritifera rochechouartii comb. nov. (Bivalvia: Margaritiferidae) revealed by time-calibrated multi- locus phylogenetic analyses... Molecular Phylogenetics and Evolution Reclassi fi cation of Lampr. Mol. Phylogenet. Evol. 120, 297-306 (2018)

12. Vaughn, C. C. \& Hakenkamp, C. C. The functional role of burrowing bivalves in freshwater ecosystems. Freshw. Biol. 46, 1431-1446 (2001).

13. Gutierrez, J. L., Jones, C. G., Strayer, D. L. \& Iribarne, O. O. Mollusks as ecosystem engineers: the role of shell production in aquatic habitats. Oikos 101, 79-90 (2003).

14. Bolotov, I. et al. Ecology and conservation of the endangered Indochinese freshwater pearl mussel, Margaritifera laosensis (Lea, 1863) in the Nam Pe and Nam Long rivers, Northern Laos. Trop. Conserv. Sci. 7 (2014).

15. Makhrov, A. et al. Historical geography of pearl harvesting and current status of populations of freshwater pearl mussel Margaritifera margaritifera (L.) in the western part of Northern European Russia. Hydrobiologia 735 (2014).

16. Cosgrove, P. et al. The status of the freshwater pearl mussel Margaritifera margaritifera in Scotland: extent of change since 1990s, threats and management implications. Biodivers. Conserv. 25, 2093-2112 (2016).

17. Sousa, R. et al. Pearl mussels (Margaritifera marocana) in Morocco: Conservation status of the rarest bivalve in African fresh waters. Sci. Total Environ. 547, 405-412 (2016).

18. Lopes-Lima, M. et al. Conservation status of freshwater mussels in Europe: state of the art and future challenges. Biol. Rev. 92, 572-607 (2017).

19. Rudzite, M., Rudzītis, M. \& Birzaks, J. The populations of the freshwater pearl mussel, Margaritifera margaritifera (Linnaeus, 1758), and the thick shelled river mussel, Unio crassus Philipsson, 1788, in Latvia. Biol. Bull. 44, 99-107 (2017).

20. Vinarski, M. \& Seddon, M. B. Margaritifera dahurica. The IUCN Red List of Threatened Species 2011: e.T189503A8740606, https:// doi.org/10.2305/IUCN.UK.2011-2.RLTS.T189503A8740606.en (2011).

21. Prozorova, L. A. Dahurinaia sujfunensis. In Red Data Book of Primoski krai: Animals. 51-52 (AVK 'Apelsin', 2005).

22. Okada, Y. \& Koba, K. Notes on the distribution of the freshwater pearl mussel, Margaritifera margaritifera in Japan. Proc. Imp. Acad. 9, 337-339 (1933).

23. Klishko, O. K. \& Bogan, A. E. The conservation status of the freshwater Pearl Mussel Margarititifera dahurica in Far Eastern Russia. Ellipsaria 15, 31-33 (2013).

24. Ziuganov, V. V., Zotin, A. A., Nezlin, L. \& Tretiakov, V. A. The freshwater pearl mussels and their relationships with salmonid fish. (VNIRO Publishing House, 1994).

25. Akiyama, Y. \& Iwakuma, T. Survival of Glochidial Larvae of the Freshwater Pearl Mussel, Margaritifera laevis (Bivalvia: Unionoida), at Different Temperatures: A Comparison Between Two Populations With and Without Recruitment. Zoolog. Sci. 24, 890-893 (2007). 
26. Kobayashi, O. \& Kondo, T. Reproductive ecology of the freshwater pearl mussel Margaritifera togakushiensis (Bivalvia:Margaritiferidae) in Japan. Venus 67, 189-197 (2009).

27. Allard, D. J., Whitesel, T. A., Lohr, S. C. \& Koski, M. L. Western Pearlshell Mussel Life History in Merrill Creek, Oregon: Reproductive Timing, Growth, and Movement. Northwest Sci. 91, 1-14 (2017).

28. O'Brien, C., Nez, D., Wolf, D. \& Box, J. B. Reproductive Biology of Anodonta californiensis, Gonidea angulata, and Margaritifera falcata (Bivalvia: Unionoida) in the Middle Fork John Day River, Oregon. Northwest Sci. 87, 59-72 (2013).

29. Hill, A. M. The Glochidia (larvae) of the Freshwater Mussel Margaritifera hembeli (Unionacea: Margaritiferidae) Fish Host Species, Morphology, and Period of Fish Host Infection. (Northwestern State University, 1986).

30. Rafael Araujo, A. \& Ángeles Ramos, M. Action plans for Margaritifera auricularia and Margaritifera margaritifera in Europe. (2001).

31. Gordon, M. E. \& Smith, D. G. Autumnal Reproduction in Cumberlandia monodonta (Unionoidea: Margaritiferidae). Trans. Am. Microsc. Soc. 109, 407 (1990).

32. Bauer, V. G. Untersuchungen zur Fortplanzungsbiologie der Flußperlmuschel (Margaritana margaritifera) im Fichtelgebirge. Arch. fur Hydrobiol. 85, 152-165 (1979).

33. Klishko, O. K. Some data on reproductive biology of the freshwater mussels (Margaritiferidae, Unionidae) and their relationships with bitterlings (Cyprinidae) in Transbaikalye. Bull. Russ. Far East Malacol. Soc. 15/16, 31-55 (2012).

34. Geist, J. Strategies for the conservation of endangered freshwater pearl mussels (Margaritifera margaritifera L.): a synthesis of Conservation Genetics and Ecology. Hydrobiologia 644, 69-88 (2010).

35. Bolotov, I. N. et al. Taxonomy and distribution of freshwater pearl mussels (unionoida: Margaritiferidae) of the Russian far east. PLoS One 10, (2015).

36. Nikolsky, G. V. Fishes of the Amur drainage. (AS USSR, 1956).

37. Antonov, A. L. Diversity of fishes and structure of ichthyocenoses in mountain catchment areas of the Amur Basin. J. Ichthyol. 52, $149-159$ (2012)

38. Zhang, J. The fishes of Heilongjiang Province. (1995).

39. Baasanjav, G., Dgebuadze, Y. Y. \& Demin, A. N. The fishes of the People Republic of Mongolia. (Nauka, 1983).

40. Chereshnev, I. A. Biogeography of freshwater fish fauna in the Russian Far East. (Dalnauka, 1998).

41. Shedko, S. V. Phylogenetic links of lenoks of genus Brachymystax (Salmonidae, Salmoniformes) and their specitations. (Lambert Academic Publishing, 2012).

42. Fish in the reserves of Russia. (The Partnership of Scientific Publications of KMK, 2010)

43. Barnhart, M. C., Haag, W. R. \& Roston, W. N. Adaptations to host infection and larval parasitism in Unionoida. J. North Am. Benthol. Soc. 27, 370-394 (2008).

44. Araujo, R. \& Ramos, M. A. Description of the glochidium of Margaritifera auricularia (Spengler 1793) (Bivalvia, Unionoidea). Philos. Trans. R. Soc. B Biol. Sci. 353, 1553-1559 (1998).

45. Kobayashi, O. \& Kondo, T. Comparative morphology of glochidia and juveniles between two species of freshwater pearl mussel Margaritifera (Bivalvia: Margaritiferidae) from Japan. Venus 65, 355-363 (2007).

46. Pekkarinen, M. \& Valovirta, I. Anatomy of the glochidia of the freshwater pearl mussel, Margaritifera margaritifera (L.). Arch. für Hydrobiol. 137, 411-423 (1996).

47. Bolotov, I. N. et al. Multi-locus fossil-calibrated phylogeny, biogeography and a subgeneric revision of the Margaritiferidae (Mollusca: Bivalvia: Unionoida). Mol. Phylogenet. Evol. 103 (2016).

48. Zolotuhin, S. P., Semenchenko, A. Y. \& Belyaev, V. A. Taimens and lenoks of the Russian Far East. (Khabarovsk branch of TINRO, 2000).

49. Kim, I.-S. \& Park, J.-Y. Freshwater Fish of Korea. (KyoHak Publishing Co. Ltd., 2002).

50. Jang, J. E. et al. Genetic diversity and genetic structure of the endangered Manchurian trout, Brachymystax lenok tsinlingensis, at its southern range margin: conservation implications for future restoration. Conserv. Genet. 18, 1023-1036 (2017).

51. Li, S. Studies on the distribution of the Salmonid fishes in China. Chinese. J. Zool. 1, 34-37 (1984).

52. Mina, M. V. Microevolution of fishes: evolutionary aspects of phenetic diversity. (South Asia Books, 1991).

53. Alekseev, S. S., Kirillov, A. F. \& Samusenok, V. P. Distribution and morphology of the sharp-snouted and the blunt-snouted lenoks of the genus Brachymystax (Salmonidae) of East Siberia. J. Ichthyol. 43, 350-373 (2003).

54. Ma, B., Yin, J.-S. \& Li, J.-P. Comparative studies on morphology and taxonomic position of two species of lenok. Acta Zootaxonomica Sin. 30, 257-260 (2005).

55. Alekseev, S. S. \& Osinov, A. G. Blunt-snouted lenoks (genus Brachymystax: Salmoniformes, Salmonidae) from the Ob' basin: New data on morphology and allozyme variation. J. Ichthyol. 46, 500-516 (2006).

56. Froufe, E., Alekseyev, S., Alexandrino, P. \& Weiss, S. The evolutionary history of sharp- and blunt-snouted lenok (Brachymystax lenok (Pallas, 1773)) and its implications for the paleo-hydrological history of Siberia. BMC Evol. Biol. 8, 40 (2008).

57. Frolov, S. V., Sakai, H. \& Frolova, V. N. Karyotypes of the lenok genus Brachymystax from the Amur River basin-AgNORs are diff erent between sharp-snouted and blunt-snouted lenoks. Chromosom. Sci. 18, 59-62 (2015).

58. Xing, Y., Fan, E., Wang, L., Zhang, C. \& Zhao, Y. Revalidation and redescription of Brachymystax tsinlingensis Li, 1966 (Salmoniformes: Salmonidae) from China, https://doi.org/10.11646/zootaxa.3962.1.12 (2015)

59. Araujo, R., Schneider, S., Roe, K. J., Erpenbeck, D. \& Machordom, A. The origin and phylogeny of Margaritiferidae (Bivalvia, Unionoida): a synthesis of molecular and fossil data. Zool. Scr. 46, 289-307 (2017).

60. Van Damme, D., Bogan, A. E. \& Dierick, M. A revision of the Mesozoic naiads (Unionoida) of Africa and the biogeographic implications. Earth-Science Rev. 147, 141-200 (2015).

61. Sytchevskaya, E. K. Palaeogene freshwater fish fauna of the USSR and Mongolia. (Nauka, 1986).

62. Wilson, M. V. H. \& Li, G.-Q. Osteology and systematic position of the Eocene salmonid †Eosalmo driftwoodensis Wilson from western North America. Zool. J. Linn. Soc. 125, 279-311 (1999).

63. Henderson, J. Fossil Non-Marine Mollusca of North America. In 1-290, https://doi.org/10.1130/SPE3-p1 (Geological Society of America, 1935).

64. Dorofeeva, E. A. Systematics and distribution history of European salmonid fishes of the genus Salmo. J. Ichthyol. 38, 419-429 (1998).

65. Chepalyga, A. L. Fossil Margaritifera of Moldavia and southwestern Ukraine. Int. Geol. Rev. 7, 1847-1857 (1965).

66. Pipoyan, S. Ichthyofauna of Armenia. History and modern condition. (Palmarium Academic Publishing, 2012).

67. Kovalchuk, OM The first appearance of Hucho (Salmonidae) in the fossil record of Eastern Europe. Vestn. Zool. 49, 413-420 (2015).

68. Taeubert, J.-E. \& Geist, J. The Relationship between the Freshwater Pearl Mussel (Margaritifera margaritifera) and its hosts. Biol. Bull. 44, 67-73 (2017).

69. Balakirev, E. S., Romanov, N. S., Mikheev, P. B. \& Ayala, F. J. Mitochondrial DNA Variation and Introgression in Siberian Taimen Hucho taimen. PLoS One 8, e71147 (2013).

70. Artamonova, V. S., Kolmakova, O. V., Kirillova, E. A. \& Makhrov, A. A. Phylogeny of salmonoid fishes (Salmonoidei) based on mtDNA COI gene sequences (barcoding). Contemp. Probl. Ecol. 11, 271-285 (2018).

71. Osinov, A. G. \& Lebedev, V. S. Genetc divergence and phylogeny of the Salmoninae based on allozyme data. J. Fish Biol. 57, 354-381 (2000).

72. Rakov, V. A. \& Brodyansky, D. L. Pearls in archaeology. Probl. Hist. Phylology Cult. 12, 462-468 (2002). 
73. Sayenko, E. M., Prokopets, S. D. \& Lutaenko, K. A. Molluscs from the medieval Bohai settlement Nikolaevskoe I (Primorye, Russian Far East): paleoecological and archaeozoological significance. Ruthenica 25, 51-67 (2015).

74. Drozdov, V. N. Far-Eastern pearl mussels. In VIII scientific conference dedicated to theoretical and practical questions of biology and parasitology. (ed. Logachev, E. D.) 70-71 (1985).

75. Jiang, Z., Jiang, J., Wang, Y., Zhang, E. \& Zhang, Y. Red List of China’s Vertebrates. Biodivers. Sci. 24, 500-551 (2016)

76. Ocock, J. et al. Mongolian Red List of Fishes. Regional Red List Series Vol. 3. (Zoological Society of London, 2006).

77. Korean Red List of Threatened Species. Second Edition. (National Institute of Biological Resources, 2014).

78. Red Data Book of the Russian Federation (animals). (AST Astrel, 2001).

79. Xu, G., Wang, F., Liu, Y., Li, Y. \& Mou, Z. Threatened fishes of the world: Brachymystax lenok (Pallas 1773). Environ. Biol. Fishes 85, 299-300 (2009).

80. Kifa, M. I. \& Vdovchenko, M. G. Incubation of eggs of lenok and taimen at the Birobidzhanski fish hatchery of Khabarovski krai. Fish. Stud. Inl. waterbodies 17, 38-42 (1979).

81. Leshta, S. S. \& Krivtsov, M. I. Ecological conditions for artificial reproduction of taimen Hucho taimen (Pallas, 1773) and lenok Brachymystax lenok (Pallas, 1773) in the Yenisei river basin with the use of temporary fish-breeding complex. Vestn. Krasn. Gos. Agrar. Univ. 8, 266-271 (2012).

82. Zhang, Y.-Y., Jia, Z.-Y., Ji, F. \& Mou, Z.-B. Effects of stocking density on survival, growth and size variation of juvenile Brachymystax lenok (Pallas, 1773). J. Appl. Ichthyol. 24, 685-689 (2008).

83. Sambrook, J., Fritsch, E. F. \& Maniatis, T. Molecular Cloning: A Laboratory Manual, (2nd ed.). (1989).

84. Folmer, O., Black, M., Hoeh, W., Lutz, R. \& Vrijenhoek, R. DNA primers for amplification of mitochondrial cytochrome c oxidase subunit I from diverse metazoan invertebrates. Mol. Mar. Biol. Biotechnol. 3, 294-299 (1994).

85. Ward, R. D., Zemlak, T. S., Innes, B. H., Last, P. R. \& Hebert, P. D. N. DNA barcoding Australia’s fish species. Philos. Trans. R. Soc. B Biol. Sci. 360, 1847-1857 (2005).

86. Šlechtová, V., Bohlen, J., Freyhof, J. \& Ráb, P. Molecular phylogeny of the Southeast Asian freshwater fish family Botiidae (Teleostei: Cobitoidea) and the origin of polyploidy in their evolution. Mol. Phylogenet. Evol. 39, 529-541 (2006)

87. Hall, T. A. BioEdit: A user-friendly biological sequence alignment editor and analysis program for Windows 95/98/NT. Nucleic Acids Symp. Ser. 41, 95-98 (1999).

88. Hoggarth, M. A. Description of some of the glochidia of the Unionidae (Mollusca:Bivalvia). Malacologia 41, 1-118 (1999).

89. Yu, Y., Harris, A. J., Blair, C. \& He, X. J. RASP (Reconstruct Ancestral State in Phylogenies): a tool for historical biogeography. Mol. Phylogenet. Evol. 87, 46-49 (2015).

90. Bauer, G. Host Relationships at Reversed Generation Times: Margaritifera (Bivalvia) and Salmonids. In 69-79, https://doi. org/10.1007/978-3-642-60725-7_5 (Springer, Berlin, Heidelberg 1997).

91. Salonen, J. K., Marjomäki, T. J. \& Taskinen, J. An alien fish threatens an endangered parasitic bivalve: the relationship between brook trout (Salvelinus fontinalis) and freshwater pearl mussel (Margaritifera margaritifera) in northern Europe. Aquat. Conserv. Mar. Freshw. Ecosyst. 26, 1130-1144 (2016).

92. Karna, D. W. \& Millemann, R. E. Glochidiosis of Salmonid Fishes. III. Comparative Susceptibility to Natural Infection with Margaritifera margaritifera (L.) (Pelecypoda: Margaritanidae) and Associated Histopathology. J. Parasitol. 64, 528 (1978).

93. Awakura, T. The ecology of parasitic glochidia of the fresh-water pearl mussel, Margaritifera laevis (Haas). Sci. Rep. Hokkaido Fish Hatch. 23, 1-21 (1968).

94. Terui, A. et al. Dispersal of larvae of Margaritifera laevis by its host fish. Freshw. Sci. 33, 112-123 (2014).

95. Kondo, T. \& Kobayashi, O. Revision of the genus Margaritifera (Bivalvia: Margaritiferidae) of Japan, with description of a new species. Venus 65, 355-363 (2005).

96. Sietman, B. et al. Cumberlandia monodonta - Host Enigma Resolved. Ellipsaria 19, 18-20 (2017).

97. Araujo, R. \& Ramos, M. A. Status and conservation of the giant European freshwater pearl mussel (Margaritifera auricularia) (Spengler, 1793) (Bivalvia: Unionoidea). Biol. Conserv. 96, 233-239 (2000).

98. Araujo, R., Bragado, D. \& Ramos, M. A. Identification of the river blenny, Salaria fluviatilis, as a host to the glochidia of Margaritifera auricularia. J. Molluscan Stud. 67, 128-129 (2001).

99. Soler, J., Boisneau, C., Wantzen, K. M. \& Araujo, R. Gasterosteus aculeatus Linnaeus, 1758, a new host fish for the endangered Margaritifera auricularia (Spengler, 1793) (Unionoida: Margaritiferidae). J. Molluscan Stud. 84, 490-493 (2018).

100. Vikhrev, I. V. et al. The revenant: rediscovery of Margaritifera homsensis from Orontes drainage with remarks on its taxonomic status and conservation (Bivalvia: Margaritiferidae). Syst. Biodivers. 16 (2018).

\section{Acknowledgements}

This study was partly funded by grants from the Federal Agency for Scientific Organizations (Project Nos 0409-2015-0143 and 0409-2016-0022), programs of the Presidium of the Russian Academy of Sciences (No. 55 $<<$ Arctic $>>$ and No. $41<<$ Biodiversity of natural systems and biological resources of Russia $>>$ ), Ministry of Education and Science of the Russian Federation (Project No. 6.2343.2017/4.6), the President of Russia Grant Council (Project No. MK-4723.2018.4), Russian Foundation for Basic Research (Project Nos 16-34-60152_ mol_a_dk, 18-34-20033_mol_a_ved, 17-45-290066_r_a, 18-05-60082, and 17-54-53085_GFEN_a), Russian Science Foundation (Project Nos 18-77-00058, 19-14-00066), and Northern Arctic Federal University. We are grateful to Yuri Tshistjakov for his excellent assistance during the fieldwork and to Sergey S. Alekseev for the confirmation of our identification of blunt- and sharp-snouted lenoks by osteological characters. Our special thanks go to the local villagers from the Elovka and Barabash-Levada villages, Primorye Region, Russian Far East, for their invaluable help in sampling of host fishes.

\section{Author Contributions}

I.V.V., A.A.M. and I.N.B. developed the concept of the study. I.N.B., A.A.M., I.N.B. and A.V.E. coordinated the samples collecting. A.V.K. and V.S.A. designed and carried out molecular analyses, with contribution from A.A.M. A.A.M. identified the fish taxa. M.B.K. and A.A.L. identified glochidia by the light microscopy. D.G.C. performed the SEM images. M.Y.G. created the maps. I.N.B. performed ancestral host reconstruction model. I.V.V. and D.G.C. pictured the samples. I.V.V. wrote the paper, with input from A.A.M., A.V.E., M.Y.G., M.B.K., A.V.K., D.G.C., A.A.L. and I.N.B. All authors approved the final version of the manuscript.

\section{Additional Information}

Supplementary information accompanies this paper at https://doi.org/10.1038/s41598-019-44752-9.

Competing Interests: The authors declare no competing interests. 
Publisher's note: Springer Nature remains neutral with regard to jurisdictional claims in published maps and institutional affiliations.

(c) (i) Open Access This article is licensed under a Creative Commons Attribution 4.0 International License, which permits use, sharing, adaptation, distribution and reproduction in any medium or format, as long as you give appropriate credit to the original author(s) and the source, provide a link to the Creative Commons license, and indicate if changes were made. The images or other third party material in this article are included in the article's Creative Commons license, unless indicated otherwise in a credit line to the material. If material is not included in the article's Creative Commons license and your intended use is not permitted by statutory regulation or exceeds the permitted use, you will need to obtain permission directly from the copyright holder. To view a copy of this license, visit http://creativecommons.org/licenses/by/4.0/.

(c) The Author(s) 2019 